\title{
SME innovation and learning: the role of networks and crisis events
}

\author{
Mark NK Saunders, University of Surrey \\ David E Gray University of Greenwich \\ Harshita Goregaokar, University of Surrey
}

\section{Biographical details}

Mark NK Saunders (author for all correspondence)

Affiliation: University of Surrey

Email address: mark.saunders@ @urrey.ac.uk

International contact details: Surrey Business School, University of Surrey, Guildford, Surrey, GU2 7XH, UK Tel +44(0)1483 686731; Fax +44(0)1483 686346

Brief personal biography: Mark NK Saunders BA, MSc, PGCE, PhD, FCIPD is Professor in Business Research Methods at the Surrey Business School, University of Surrey. His research interests include trust, research methods, organisational learning and SMEs. His research findings have been published in a range of academic and practitioner journals. Recent books include: Handbook of methods for researching trust (2012, Edward Elgar) coedited with Fergus Lyon and Guido Möllering; and Research Methods for Business Students (2012, Pearson Education) co-authored with Phil Lewis and Adrian Thornhill.

David E Gray

Affiliation: University of Greenwich

Email address: d.e.gray@gre.ac.uk

International contact details: Greenwich Business School, University of Greenwich, 30 Park Row, Greenwich, London SE10 9LS, UK Tel +44(0)20 83318000

Brief personal biography: David E Gray (BSc (Econ), MA(Ed), MSc, Cert Ed., PhD, FRSA) is Professor of Leadership and Organisational Behaviour at the University of Greenwich. His research interests, and publication record, include research methods, management learning (particularly coaching and mentoring), action learning, reflective learning, and learning in SMEs. He has written books and published articles on research methods, work-based learning, and coaching and mentoring. David has led a number of coaching research programmes both for managers of SMEs, for unemployed managers who seek new employment opportunities and for unemployed managers who aim to start their own business. 
Harshita Goregaokar

Affiliation: University of Surrey

Email address: harshita.goregaokar@surrey.ac.uk

International contact details: Surrey Business School, University of Surrey, Guildford, Surrey, GU2 7XH, UK

Brief personal biography: Harshita Goregaokar BA (Psychology), MA (Clinical Psychology), MSc (Work and Organisational Psychology) is currently pursuing part-time $\mathrm{PhD}$ from the University of Surrey. She has previously held research posts at the University of Surrey and the University of Kent. Her research interests and publication record, include executive coaching and mentoring, reflective learning, sensemaking and unemployment. Harshita has worked on several UK and European government research programmes involving coaching for SME managers, for unemployed managers who seek new employment opportunities and for unemployed managers who aim to start their own business.

\section{Acknowledgement:}

We would like to thank Kingston Smith LLP for financing this research project, the many businesses and individuals who took part, and the many organisations such as Chambers of Commerce that promoted the research survey amongst their membership. 


\title{
SME innovation and learning: the role of networks and crisis events
}

\author{
Short title: SME innovation and learning
}

\begin{abstract}
Purpose: To contribute to the literature on innovation and entrepreneurial learning by exploring how SMEs learn and innovate, how they use of both formal and informal learning and in particular the role of networks and crisis events within their learning experience. Design/methodology/approach: Mixed method study, comprising 13 focus groups, over 1000 questionnaire responses from SME mangers, 13 focus groups and 20 case studies derived from semi-structured interviews.

Findings: SMEs have a strong commitment to learning, and a shared vision. Much of this learning is informal through network events, mentoring or coaching. SMEs that are innovative are significantly more committed to learning than those which are less innovative, seeing employee learning as an investment. Innovative SMEs are more likely to have a shared vision, be open-minded and to learn from crises, being able to reflect on their experiences.

Implications for research: There is a need for further process driven qualitative research to understand the interrelationship between, particularly informal, learning, crisis events and SME innovation.

Implications for practice: SME owners need opportunities and time for reflection as a means of stimulating personal learning - particularly the opportunity to learn from crisis events. Access to mentors (often outside the business) can be important here, as are informal networks.

Originality/value: This is one of the first mixed method large scale studies to explore the relationship between SME innovation and learning, highlighting the importance of informal learning to innovation and the need for SME leaders to foster this learning as part of a shared organisational vision.
\end{abstract}

Key words: SME, entrepreneur, learning, innovation, network, crisis event, mixed method.

Categorization: research paper. 


\section{Introduction}

In the context of European countries, approximately $99 \%$ of all businesses are classified as micro or small in terms of the numbers employed and annual turnover (European Commission, 2010). Within the UK there are approximately 4.5 million small and medium sized enterprises (SMEs) providing 13.7 million jobs equating to over half of the private sector workforce in 2011 (Department of Business Innovation and Skills, 2012). Such SMEs $^{1}$ are considered one of the driving forces of the market economy (Philip, 2011) and a major source of economic growth. Indeed, such is their importance that they have emerged as a theoretically distinct category for research purposes (Blackburn and Kovalainen, 2009). However whilst SMEs are important, it is their success that is of greater significance to continued economic prosperity (Holmes et al., 2010).

This paper takes as its starting point the proposition that innovation and learning orientation are key factors in SME success. Its purpose is to contribute to the literature on the relationship between innovation and entrepreneurial learning by exploring how entrepreneurs learn and innovate, their use of both formal and informal learning and the role of networks and crisis events within their learning experience.

\section{Theoretical base}

Researchers have focused on a range of themes that might determine the success, or otherwise, of SMEs. These have included: the entrepreneur, including their entrepreneurial (innovation) and learning orientations, skills and motivation (Jasra et. al., 2011; Storey,

\footnotetext{
${ }^{1}$ Defined by European Union recommendation L124/36 (2003) as (1) under 250 employees; (2) annual assets under 43 million Euros; (3) business turnover under 50 million Euros
} 
1994); the nature of the firm (Storey 1994; Storey and Wynarczyk, 1996); its business strategy (Holmes et al., 2011, Storey, 1994; Pelham, 2000), and the relationship between HRM (Human Resource Management) practices and performance (Sheehan, 2013). Vereynne et al., (2011) found a positive association between SME performance and high performance work systems including organisational learning orientation and employee skill development. Yet at the same time writers on HRD in small firms have highlighted its predominantly unplanned and reactive nature (Vickerstaff and Parker 1995, informal and idiosyncratic approaches being used (Hill and Stewart, 2000; Kitching, 2007). Whilst such HRD practices (and the associated learning) have often been discussed in pejorative terms and characterising as less sophisticated and insufficient compared to larger firms (Nolan and Garavan, 2012).

An SME's learning orientation rests on three factors which underpin adaptive and generative learning (Wang, 2008): (1) commitment to learning and the emphasis this is given (Wang 2008); (2) open-mindedness including proactive questioning of long-held assumptions and beliefs (Sinkula et al., 1997); and (3) shared organizational vision (Baker and Sinkula, 1999). Adaptive learning entails sequential and incremental learning within the scope of traditional organizational activities. However, for an SME to seize unconventional business opportunities it has to be willing to innovate (Wang, 2008), question established assumptions about its mission, customers, capabilities or strategy and engage with higher order or generative learning. The ability to do this, is facilitated if businesses are willing to engage in social learning processes and networking (Wolfe and Gertler, 2002), the very informal HRD processes considered less sophisticated and insufficient. 
For the purposes of this study, networking is defined as 'the action by which an ownermanager develops and maintains contacts for trading and business development purposes' (Chell and Baines, 2000: 196). Social learning stresses that innovation is a highly social enterprise, the ability within and across firms to learn being critical to the innovation process (Wolfe and Gertler 2002). For those businesses where technological change is rapid, firm survival and growth requires heightened reflexivity focussed on continual, and strategic, learning through (amongst other things) interaction with suppliers and end-users of products and services. In a study of 159 SMEs, Hyvonen and Tuominen (2005) found that technological innovation capability and strong relationships with customers and supply chain partners are the key determinants of successful economic performance. Yet it is the firm's commitment to learning that strengthens its position (Wang, 2008). Managerial innovation is, in part, contingent on this learning orientation. Similarly, an in-depth study of one UK SME, where $50 \%$ of its annual turnover comes from new products, a learning culture permeated the organisation through: 'an open culture where challenge, doubt, and changing one's mind are the accepted way of things' (Barnett and Storey, 2001: 11). The focus was not just on product development, but personal development and interaction.

Entrepreneurial learning is a continuous process whereby practical wisdom is derived from experience (Politis, 2005), including failure and critical incidents. It includes the ability to learn from new venture creation, as well as once the new business is established (Cope, 2005). As SMEs grow this may trigger developmental crises at both a personal and organizational level (Cope and Watts, 2000). Although often stressful and even traumatic, such crisis events can also be transformational for both the entrepreneur and organization (Beresford and Saunders, 2005). Within this, critical incidents may generate processes for learning and growing self-awareness, and be seminal within the process of change. However, 
whether critical incidents generate learning largely depends on whether the entrepreneur is able to engage in both 'single' and 'double-loop' learning and reflection.

A study of 27 UK firms, found that the ability to 'stand back' from the business and reflect on the learning that had taken place was vital (Sullivan, 2000). Such learning was nurtured both by formal programs (for example, management courses) and informally through mentoring and networks. Learning is also fostered through networking, defined here as making use of information, advice, support or assistance from people who are not part of the business or the family (Chell and Baines, 2000). The link between SME learning and networking, however, is contested. Curran at al. (1993) suggest a 'fortress enterprise' proposition where SMEs do not make use of business networks or engage in any networking activities beyond those of direct relevance to the business. In contrast, Chell and Baines (2000), in a study of 104 owner-managers, showed that SMEs made use of both customers and other owner managers, even keeping touch with former employees as a source of information. Of the formal, institutional support networks, Chambers of Commerce were the most frequent mentioned, cited by $38 \%$ of respondents, providing access to relatively diverse sources of possible information and advice through their members. Overall, two-fifths of the businesses were either highly active or relatively active in networking that was either business related or a combination of business and social.

Granovetter (1985) distinguishes between the 'strong ties' of family and close friends and the weak ties typical of business networks. Strong ties are a reflection of the amount of time, emotional intensity, intimacy and reciprocal services between people. They are typically associated with high levels of trust and the flow of fine-grained information (Nahapiet and Ghoshal, 1998). Being embedded in a network can give rise to a form of trust known as 
relational trust, which develops over time and is based on continual reciprocity (Rousseau et al., 1998) - 'I will do this for you now, but you will do something for me later'. The downside is that they are also likely to share similar contacts and information, much of which is therefore redundant (the 'echo-chamber' syndrome). Weak ties may be of short duration and low frequency but, like for example Chambers of Commerce; they enable the individual to draw upon information, advice and assistance from a large, diverse pool.

\section{Research design}

The research adopted a mixed method approach, combing both quantitative and qualitative data collection techniques (Tashakkori and Teddlie, 2010). Six exploratory focus groups were conducted with SMEs who had been in business for at least five years, selected to ensure maximum variation across the United Kingdom (UK) Government's standard industrial sectors. Resultant themes, which we termed 'triggers for success' included maintaining adequate cash flow, engaging with traditional networks and social networks and learning orientation, were subsequently triangulated through a further focus group with a critical case sample of subject matter experts. These themes, along with the academic literature reviewed above, informed the online questionnaire.

\section{Survey Measures}

The questionnaire comprised 82 Likert style closed questions relating to entrepreneurial and learning orientations (derived from Wang, 2008) and a further 13 questions collecting demographic data. Within entrepreneurial research, measures of entrepreneurial orientation are normally derived from the Miller/Covin and Slevin scale (Brown et al., 2001), Wiklund (1998) arguing that this is a viable measure for measuring business level entrepreneurship. 
Following more recent work by Wang (2008) we also adopted this scale, the Cronbach's alpha value across all items indicating good internal consistency (George and Mallory, 2003). Sub scales measured SMEs' market proactiveness, competitive aggressiveness, risk taking and innovativeness; Cronbach's alpha values or the first two subscales indicating internal consistency (Table 1). . Wang (2008) argues that most entrepreneurial research that considers innovation focuses upon the product market and technological aspects of innovation, ignoring new ways of thinking and behaving. We therefore adopted her three-item sub scale of firm innovativeness, which focuses upon the latter; Cronbach's alpha values indicating this was internally consistent (Table 1). The Cronbach's alpha value for the risk taking sub scale suggested internal consistency was questionable (Table 1). Removing Wang's (2008) reverse coded item 'When there is uncertainty our business typically adopts a wait-and-see posture in order to minimise the probability of making costly decisions' ensured good internal consistency; the amended scale still no longer reflecting SMEs' risk taking in times of uncertainty

Our questionnaire adopted Sinkula et al.'s (1997) scale to measure learning orientation, comprising three sub scales measuring commitment to learning, shared vision and open mindedness (Table 1). Following focus groups which highlighted the importance of crisis events to learning, we added a further subscale 'learning from crises" comprising two items: "We learn from crisis events that are critical for our business" and "Crisis events have led us to change the way we do things". Overall the internal consistency for this new 13 item learning orientation scale was excellent (Table 1). 


\section{The Population \& Sample}

Given acknowledged difficulties of accessing SMEs (Curran and Blackburn, 2000), a series of databases offering coverage of the UK were combined to ensure a sufficient coverage. These comprised:

- SMEs throughout the UK drawn from a commercial database $(36.1 \%)$

- Members of selected Chambers of Commerce in the South East, Midlands and North of England and other employer groups such as the Institute of Directors (36.8\%)

- Directories of small businesses $(21.8 \%)$

- Existing SME contacts (5.3\%).

Following a pilot test we delivered the questionnaire to private sector SMEs (i.e. those with fewer than 250 employees via an email link to a survey web site; four per cent of respondents completed the survey through a telephone interview conducted by a small research team, we briefed for this purpose. The response rate for the commercial database was affected significantly by firewalls or bounce backs, only $56 \%$ of emails reaching their destination. For these 6084 potential participants response rates were still poor, only $578(9.5 \%)$ of eligible SMEs responding Response rates for Members of selected Chambers of Commerce in the South East, Midlands and North of England, other employer groups; and for directories of small businesses could not be calculated as the direct mailing of questionnaires by these organisations prevented establishing how many emails met their target SME. However these two groups accounted for 589 and 349 of all responses respectively. The remaining 84 responses came from existing SME contacts.

Overall some 1,664 questionnaires were returned of which 1,600 contained responses that met the private sector and size criteria. Of the 1,600 questionnaires, 1,004 had $80 \%$ or more 
of the questions answered, this number rising to 1,023 when only crucial, that is questions relating directly to the purpose of the questionnaire, are considered. Following the American Association for Public Opinion Research (2008), these are considered 'complete' returns. Demographic data from the returned data were compared with the UK Department of Business Innovation and Skills (2012) data on private sector SMEs. SMEs from certain UK regions, in particular the South East excluding London, are significantly over-represented (Table 2). The proportions of SMEs in certain sectors, notably Professional, Scientific and Technical activities, Information and Communication and Other Service activities are overrepresented (Table 3). The proportion of SMEs in certain sectors, notably Construction and Agriculture, Forestry and Fishing are under-represented (Table 3). Analysis does not consider such regional and sector differences, except where it makes a significant impact.

\section{Semi-structured interviews}

Subsequently 20 qualitative, semi-structured interviews were conducted with a heterogeneous sample of SMEs to explore key themes and develop deeper understandings. These interviews, which comprised a semi-structured interview schedule with follow-up, probing questions around emerging themes, were approximately one hour in length. With the permission of all respondents, these were audio recorded for subsequent transcription for data analysis. In this mixed method study, data analysis used an interdependent approach, interview transcripts from the 20 case-study SMEs being used to deepen understanding of key themes identified in the quantitative analysis (Gray, 2009; Saunders et al., 2012). 


\section{Findings - the relationship between innovation and learning and the role of crises}

\section{The nature of innovativeness}

SMEs innovativeness comprises their active response to the adoption of new ways of doing things (such as innovations in processes) by their main competitors, their willingness to try new ways of acting and seeking unusual, novel solutions and their encouraging employees to think and behave in original and novel ways (Wang 2008). SMEs with high levels of firm innovativeness will score highly on Wang's (2008) three item subscale. Within our sample, responses varied between the three items. Whilst over $80 \%$ of SMEs agreed, at least to some extent, that their business was willing to try new ways of doing things and seek unusual and novel solutions and encouraged employees think and behave in original and novel ways, the percentage of those agreeing that they actively responded to the adoption of new ways of doing things by their competitors was less than 70\% (Table 3). Case study analysis, however, revealed plentiful examples of SMEs adopting flexible strategies for innovation, including facing up to overseas competition by aggressively switching to overseas sales (Cases 3 and 10), making use of social media for interacting with suppliers and customers (Cases 8 and 9) and outsourcing work to other SMEs who identify with the business (Case 5).

\section{The nature of learning orientation}

SMEs with a strong Learning Orientation (LO) score highly on the 11 items in Sinkula et al.'s (1997) scale and the additional two items in the learning from the crises subscale. Within our sample, over $80 \%$ of respondents agreed, at least to some extent for all scale items regarding their business's commitment to learning (Table 5). Commitment to learning was strongest for SMEs established more recently, One-way Analysis of Variance indicating this difference was significant $(F(2,885)=3.054, \mathrm{p}=.048)$. In marked contrast (Table 5) there 
was less agreement for scale items relating to open mindedness, particularly with regard to questioning the way in which customer information (less than $55 \%$ agreeing) and questioning the marketplace (less than 65\% agreeing). Agreement with regard to some aspects of shared vision and learning from crises was also less pronounced. For shared vision this was particularly with regard to employees who viewed themselves as partners in charting the direction of the business, whilst for learning from crises, it related to crisis events leading the business to change the way they did things (both less than 70\%). Case study data highlighted that, for some businesses, learning from crisis events was vital. Crisis events teach managers that they have to work hard to get anywhere in business and not to take anything for granted. These crisis events often left a lasting effect on the SMEs and their owners. "The crisis has "aged us a couple of years", but it has also made the company stronger, leaner and fitter" (Case 13).

Conducting a series of One-way Analyses of Variance highlighted that, unlike other aspects of LO, shared vision differed significantly $(F(2,936)=9.209, \mathrm{p}<.000)$ between micro and small, and medium sized enterprises, being lower for medium sized enterprises. It also differed significantly $(F(2,872)=3.794, \mathrm{p}=.023)$ when the SME was established, being more pronounced for those more recently established.

Focus group and case study data further emphasise that SMEs value learning whether formal through accredited programmes or informal. In particular these data emphasise that while some SMEs engage with formal learning programmes, such as an MBA this was relatively uncommon. For most, making use of informal learning opportunities, such as the use of a mentor or coach was important. Getting an external perspective, often through networking activities from a range of groups, whether it be peer groups, Managing Director groups 
(talking to fellow directors can be "hugely powerful"), breakfast seminars or casual conversations, was found to help in "chewing over the business” (Case 16) as “...you are cocooned and isolated as an SME". Case participants highlighted how, for example, if there was a dip in business, they could discuss this with competitors to establish whether it was a market trend, or a due to a mistake they had made. Whilst for such informal learning through networking there was no formal development course or agenda, participants argued there was "always a nugget" that comes out, the entrepreneur feeling "Yes, that's something that I can work with". It is conversations that trigger ideas (Case 4).

\section{Innovativeness and learning orientation}

Pearson's correlation analysis indicated that SMEs that were more innovative were significantly more committed to learning than those which were less innovative $(r(976)=$ $.476, p<.000)$. In particular One-way Analysis of Variance revealed SMEs that were more innovative were more likely to agree that employee learning as an investment, not an expense $(F(6,973)=40.385, \mathrm{p}<.000)$, to agree that their ability to learn was their competitive advantage $(F(6,977)=38.517, \mathrm{p}<.000)$ and that the basic values of their business included learning as a key to improvement $(F(6,976)=35.802, \mathrm{p}<.000)$ and that learning was seen as a key commodity necessary to guarantee business survival $(F(6,973)=25.355, \mathrm{p}<.000)$.

Our correlation analysis indicated these innovative businesses were also significantly more likely to have a shared vision $(r(960)=.374, p<.000)$, be open minded $(r(961)=.360$, $p<.000)$ and to a lesser extent learn from crises $(r(968)=.253, p<.000)$. In particular Oneway Analysis of Variance highlighted they were more likely to agree that there was a commonality of purpose in their business $(F(6,971)=26.588, \mathrm{p}<.000)$ and that their 
employees realised the very way they perceived the marketplace must be continually questioned $(F(6,962)=23.128, \mathrm{p}<.000)$.

In terms of Entrepreneurial Orientation, case study data revealed participants demonstrated high levels of commitment, proactiveness and "persistence in adversity" (Cases 3 and 14). For example, failure was viewed as just part of a learning process (Case 15); you "learn from experiences". When autonomy was mentioned it was always in a positive light, none of the entrepreneurs wanting to return to the corporate or salaried world. "I am in control" (Case 14) and "no one's going to turn the lights out on me" (Case 15). In terms of the corporate world (even though some have worked there), they often regarded themselves as no longer employable by such organisations. Entrepreneurial Orientation included being "open minded" or "open eared" at all times, being prepared to listen (Case 12). It also meant showing drive and determination and being persistent - because success always took longer than expected. The downside of this entrepreneurial spirit is that excessive focus can result in being too blinkered and unwilling to countenance their own weaknesses or mistakes; in other words not really learning from crises. Some participants highlighted they should have had the humility to step back and admit they were wrong. They, like others, argued that the creative but reckless would not survive. Not surprisingly the SMEs argued they and others were cautious about risk because they were usually investing their own money!

Many SMEs purchase external advice, but tend to be highly selective as to what kind of advice they need, focusing primarily on the services of accountants, HR specialists, and IT consultants rather than advice on learning. SMEs were outward (customer) facing, whereas external advice is usually sought to solve back office issues which SMEs regard as necessary but less rewarding. Both the issues themselves, and the external professional advice on offer, 
are usually fragmented. Rather than pay for advice, some SMEs are turning to social media, live networks or informal management learning groups where they can discuss business problems with experienced fellow business owners.

\section{Conclusions and implications for practice}

SMEs' learning occurs at two levels. Learning Orientation is about how learning flows within and across the business - it is about having a shared vision and being able to question direction and assumptions. Entrepreneurial learning is about individual learning both from personal engagement with programmes but more often, and more importantly through conversations within social networks. It is this informal HRD that appears crucial to SMEs.

The study showed that SMEs that were more innovative were significantly more committed to learning (Learning Orientation) than those that were less innovative, including the personal learning of leaders and directors and the learning of their employees. For SME leaders, their own learning was usually informal in nature, being through network events such as breakfast seminars or Managing Director groups and interactions with a mentor or coach (particularly a mentor). Such development often involved having an opportunity to improve their reflective learning through receiving feedback or advice on recent critical incidents. Conversations that trigger ideas, and social networks, live and informal rather than virtual and formalised, were crucial to this development.

A number of issues emerge for practice. SME owners need opportunities and time for reflection as a means of stimulating personal learning - particularly the opportunity to learn 
from crisis events. Access to mentors (often outside the business) can be important here, as are informal networks. Time spent engaging in informal conversations with other ownermanagers needs to be considered as an investment not a cost. But the learning of others in and across the business is also vital. As SMEs grow in size, this can become more challenging as communications channels become more complex. SME leaders need to foster this learning as part of a shared organisational vision.

\section{References}

American Association for Public Opinion Research. (2008). Standard Definitions: Final Dispositions of Case Codes and Outcome Rates for Surveys ( $5^{\text {th }}$ ed.). Lenexa, KA:

\section{AAPOR.}

Baker, W.E. and Sinkula, J.M. (1999) 'The synergistic effect of market orientation and learning orientation on organizational performance' Journal of the Academy of Marketing Science. 27(4) 411-560.

Barnett, E. and Storey, J. (2001) 'Narratives of Learning, Development and Innovation: Evidence from a Manufacturing SME'. Enterprise and Innovation Management Studies, 2(2): 83-101.

Beresford, R. and Saunders, M.N.K. (2005) 'Professionalization of the business start-up process' Strategic Change, 14, 337-347.

Blackburn, R. and Kovalainen, A. (2009) 'Researching small firms and entrepreneurship: Past present and future. International Journal of Management Reviews, 11, 127-148.

Brown, T.E., Davidsson, P., \& Wiklund, J. (2001). An operationalization of Stevenson's conceptualization of entrepreneurship as opportunity-based firm behavior. Strategic Management Journal, 22, 953-968 
Chell, E. and Baines, S. (2000) 'Networking, entrepreneurship and microbusiness behaviour'. Entrepreneurship and Regional Development, 12, 195-215.

Cope, J. (2005) 'Toward a dynamic learning perspective of entrepreneurship' Entrepreneurship, Theory and Practice, 29(4) 373-397.

Cope, J. and Watts, G. (2000) 'Learning by doing: an exploration of experience, critical incidents and reflection in entrepreneurial learning' International Journal of Entrepreneurial Behaviour 6(3) 104-124.

Curran, J., Jarvis, R., Blackburn, R. A. and Black, S. 1993 Networks and small firms: constructs, methodological strategies and some findings. International Small Business Journal, 11(2): 13-25.

Curran, J and Blackburn, R. (2000) Researching the small enterprise. London: Sage. Department for Business Innovation and Skills (2012) Business Population Estimates for the UK and Regions 2011. [Accessed 21 October 2012] Available at http://stats.bis.gov.uk/ed/bpe

European Commission (2010). Small and medium-sized enterprises (SMEs): Facts and figures about the EU's Small and Medium-sized enterprise (SMEs). [online] (cited 20th April 2011), Available from http://ec.europa.eu/cgi-bin/etal.pl

George, D., \& Mallery, P. (2003). SPSS for Windows step by step: A simple guide and reference. 11.0 update (4th ed.). Boston: Allyn \& Bacon.

Gray, D.E. (2009) Doing Research in the Real World, $2^{\text {nd }}$ edn. London: Sage.

Granovetter, M. (1985) 'Economic action and social structure: the problem of embeddedness', American Journal of Sociology, 91: 481-510.

Hill, R. and Stewart, J. (2000) Human Resource Development in Small Organisations. Journal of European Industrial Training, 24: 105-117. 
Holmes, P., Hunt, A. and Stone, I. (2010) 'An analysis of new firm survival using a hazard function' Applied Economics, 42, 185-195.

Hyvonen, S. and Tuominen, M. (2006) 'Entrepreneurial innovations, market-driven intangibles, and learning orientation: critical indicators for performance advantages in SMEs' International Journal of Management and Decision Making, 7(6): 643-660.

Jasra, J.M., Khan, M.A., Hunjra, A.I., Rehman, R.A.U. \& Azam, R-I. (2011) ‘Determinants of Business Success of Small and Medium Enterprises' International Journal of Business and Social Science 2(20) 274-280.

Kitching, J. (2007) Regulating employment relations through workplace learning: a study of small employers. Human Resource Management Journal, 17, 42-57.

Nahapiet, J. \& Ghoshal, S. (1998) 'Social capital, intellectual capital and the organizational advantage'. Academy of Management Review, 23(2), 242-266.

Nolan C and Garavan T (2012) Lost in translation? Critiquing the HRD discourse in the small firm, Working paper. Limerick: University of Limerick

Pelham, A.M. (2000) 'Market Orientation and Other Potential Influences on Performance in Small and Medium-Sized Manufacturing Firms' Journal of Small Business Management 38(1) 48-67.

Philip, M. (2011) 'Factors Affecting Business Success of Small \& Medium Enterprises (SMEs)’ Amity Global Business Review 6(1) 118-136.

Politis, D. (2005) 'The Process of Entrepreneurial Learning: A Conceptual Framework' Entrepreneurship, Theory and Practice, 29(4) 399-424.

Rousseau, D.M., Sitkin, S.B. Burt, R.S. and Carmerer, C. (1998) 'Not so Different After All: a Cross-Discipline View of Trust', Academy of Management Review 23, 393-404.

Saunders, M., Lewis, P. and Thornhill, A. (2012) Research Methods for Business Students. Harlow: Pearson. 
Sheehan, M. (2013) 'Human Resource Management and Performance: Evidence from Small and Medium Sized Firms', International Small Business Journal [eprint ahead of publication] doi: 10.1177/0266242612465454.

Sinkula, J.M., Baker, W.E., and Noordewier, T. (1997) ‘A framework for market-based organizational learning: Linking values, knowledge, and behaviour' Journal of the Academy of Marketing Science, 25(4), 305-318.

Storey, D.J. (1994) 'Understanding the small business sector' London: Thomson Publishing.

Storey, D.J. and Wynarczyk, P. (1996) 'The Survival and Non Survival of Micro Firms in the UK' Review of Industrial Organization 11: 211-229.

Sullivan, R. (2000) ‘Entrepreneurial learning and mentoring’ International Journal of Entrepreneurial Behaviour \& Research. 6(3) 160-175.

Tashakkori, A. and Teddlie, C. (eds) (2010). The Sage Handbook of Mixed Methods in Social and Behavioural Research (2 ${ }^{\text {nd }}$ edn. $)$. Thousand Oaks, CA: Sage.

Verreynne M-L, Parker P and Wilson M (2011) Employment systems in small firms: A multilevel analysis. International Small Business Journal. 24 (1) 1-27.

Vickerstaff, S. and Parker, K. T. (1995) Helping Small Firms: The Contribution of TECs and LECs. International Small Business Journal, 16, 56-72.

Wang, C.L. (2008) 'Entrepreneurial Orientation, Learning Orientation, and Firm Performance' Entrepreneurship, Theory and Practice, 32(4) 635-657.

Wolfe, D.A. and Gertler, M.S. (2002) 'Innovation and Social Learning: An Introduction'. pp. 1-24. In M.S. Gertler and D.A. Wolfe (eds.), Innovation and Social Learning: Institutional Adaptation in an Era of Technological Change. Basingstoke and New York: Palgrave Macmillan. 
Table 1: Survey measures

\begin{tabular}{|l|l|r|r|}
\hline Scale/Sub scale & Source & $\begin{array}{l}\text { Number of } \\
\text { items }\end{array}$ & $\begin{array}{l}\text { Cronbach's } \\
\text { alpha }\end{array}$ \\
\hline Entrepreneurial orientation $\mathbf{( 1 , 2 , 3 , 4 )}$ & Wang (2008) & 11 & .783 \\
1. Market proactiveness & & 3 & .619 \\
2. Competitive aggressiveness & & 2 & .675 \\
3. Firm innovativeness & & 3 & .733 \\
4. Risk taking & & 3 & .540 \\
4b. Risk taking (1 item removed) & & 2 & .750 \\
& & & \\
Learning orientation $(\mathbf{1 , 2 , 3 )}$ & Sinkula et al., (1997) & 11 & .873 \\
1. Commitment to learning & & 4 & .889 \\
2. Shared vision & & 4 & .859 \\
3. Open mindedness & & 3 & .540 \\
4. Learning from crises (new sub scale) & this study & 2 & .785 \\
Learning orientation $(1,2,3,4)$ & (see above) & 13 & .856 \\
\hline
\end{tabular}

Table 2: Location of business

\begin{tabular}{|l|r|r|}
\hline Planning region & $\begin{array}{c}\text { Survey } \\
\mathrm{N} \%\end{array}$ & \multicolumn{1}{c|}{$\begin{array}{c}\text { UK } \\
\text { N } \%\end{array}$} \\
\hline North East & $2.4 \%$ & $2.6 \%$ \\
North West & $6.6 \%$ & $10.0 \%$ \\
Yorkshire and the Humber & $4.8 \%$ & $7.3 \%$ \\
East Midlands & $4.8 \%$ & $6.8 \%$ \\
West Midlands & $5.8 \%$ & $7.3 \%$ \\
East of England & $4.0 \%$ & $10.4 \%$ \\
South East (excluding London) & $42.9 \%$ & $16.4 \%$ \\
London & $12.7 \%$ & $16.5 \%$ \\
South West & $6.5 \%$ & $9.4 \%$ \\
Wales & $1.9 \%$ & $4.2 \%$ \\
Scotland & $3.9 \%$ & $6.4 \%$ \\
Northern Ireland & $3.6 \%$ & $2.7 \%$ \\
\hline Total (=100\%) & 1,181 & $4,536,445$ \\
& & \\
\hline
\end{tabular}

Survey total refers only to respondents answering the actual question

* Source: Department of Business Innovations and Skills (2012) 
Table 3: Industry

\begin{tabular}{|l|r|r|}
\hline Standard Industrial Classification & $\begin{array}{r}\text { Survey } \\
\text { N } \%\end{array}$ & \multicolumn{1}{c|}{ UK $\%$} \\
\hline Agriculture, Forestry and Fishing & $.6 \%$ & $3.2 \%$ \\
Mining and Quarrying, Electricity, Gas, Steam and Air Conditioning & $2.0 \%$ & $.6 \%$ \\
Supply, Water Supply, Sewerage, Waste Management and & & \\
Remediation & & \\
Manufacturing & $10.0 \%$ & $4.9 \%$ \\
Construction & $5.0 \%$ & $20.6 \%$ \\
Wholesale and Retail Trade, Repair of Motor Vehicles and & $6.5 \%$ & $9.0 \%$ \\
Motorcycles & & \\
Transportation and Storage & $2.5 \%$ & $5.9 \%$ \\
Accommodation and Food Service Activities & $1.4 \%$ & $1.5 \%$ \\
Information and Communication & $11.8 \%$ & $6.2 \%$ \\
Financial and Insurance Activities & $6.7 \%$ & $1.9 \%$ \\
Real Estate Activities & $2.7 \%$ & $1.8 \%$ \\
Professional, Scientific and Technical Activities & $22.2 \%$ & $13.7 \%$ \\
Administrative and Support Service Activities & $5.1 \%$ & $7.6 \%$ \\
Human Health and Social Work Activities & $3.7 \%$ & $7.2 \%$ \\
Education & $4.2 \%$ & $5.6 \%$ \\
Arts, Entertainment and Recreation & $3.4 \%$ & $4.7 \%$ \\
Other Service Activities & $11.1 \%$ & $5.7 \%$ \\
(Other, please say) & $1.1 \%$ & \\
\hline Total (=100\%) & 967 & $4,536,445$ \\
& & \\
\hline
\end{tabular}

Survey total refers only to respondents answering the actual question

* Source: Department of Business Innovations and Skills (2012) 
Table 4: Respondents' opinions on their businesses' Entrepreneurial Orientation

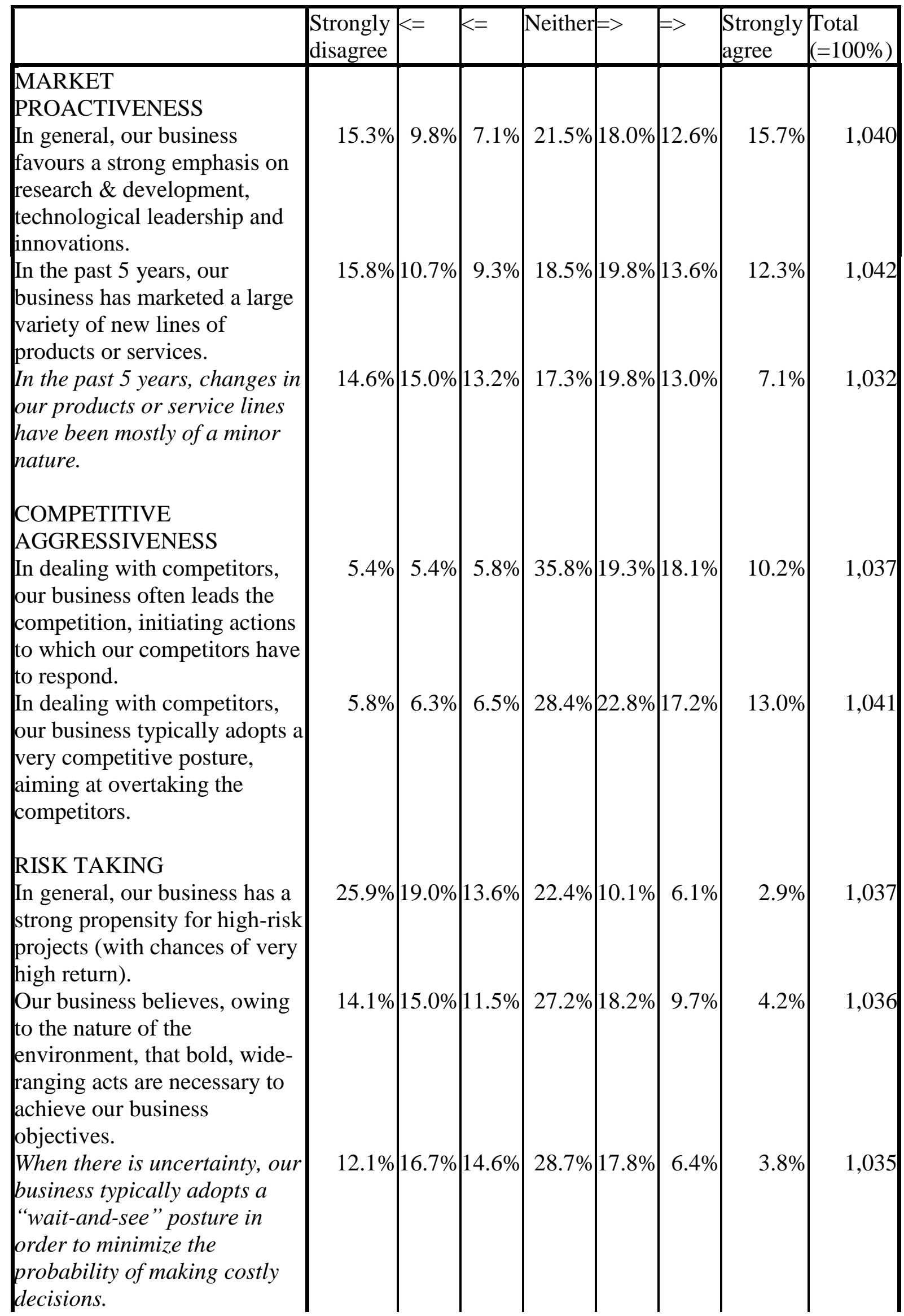




\begin{tabular}{|l|l|l|l|l|l|l|l|r|} 
INNOVATIVENESS & & & & & & \\
$\begin{array}{l}\text { Our business actively } \\
\text { responds to the adoption of } \\
\text { "new ways of doing things" } \\
\text { by main competitors. }\end{array}$ & $2.9 \%$ & $3.8 \%$ & $6.0 \%$ & $23.5 \%$ & $34.7 \%$ & $19.7 \%$ & $9.5 \%$ & 1,035 \\
$\begin{array}{l}\text { Our business is willing to try } \\
\text { new ways of doing things and } \\
\text { seek unusual, novel solutions. } \\
\text { Our business encourages } \\
\text { employees to think and } \\
\text { behave in original and novel } \\
\text { ways. }\end{array}$ & $1.5 \%$ & $1.3 \%$ & $1.3 \%$ & $8.3 \%$ & $25.8 \%$ & $35.0 \%$ & $26.8 \%$ & 1,040 \\
\hline
\end{tabular}

Total refers only to respondents answering the actual survey question

Statements in italics are worded in reverse outlook to others. 
Table 5: Respondents' opinions on their businesses' Learning Orientation

\begin{tabular}{|c|c|c|c|c|c|c|c|c|}
\hline & $\begin{array}{l}\text { Strongly } \\
\text { disagree }\end{array}$ & $k=$ & $k=$ & Neither & $\mathrm{r}=>$ & $\Rightarrow>$ & \begin{tabular}{|l} 
Strongly \\
agree
\end{tabular} & $\begin{array}{l}\text { Total } \\
(=100 \%)\end{array}$ \\
\hline $\begin{array}{l}\text { COMMITMENT TO } \\
\text { LEARNING }\end{array}$ & & & & & & & & \\
\hline $\begin{array}{l}\text { Our business agrees that our } \\
\text { ability to learn is our } \\
\text { competitive advantage. }\end{array}$ & $.6 \%$ & $1.2 \%$ & $1.6 \%$ & $8.7 \%$ & $24.6 \%$ & $29.7 \%$ & $33.6 \%$ & 1,007 \\
\hline $\begin{array}{l}\text { The basic values of this } \\
\text { business include learning as a } \\
\text { key to improvement. }\end{array}$ & $.4 \%$ & $1.0 \%$ & $1.3 \%$ & $8.2 \%$ & $24.1 \%$ & $31.7 \%$ & $33.3 \%$ & 1,005 \\
\hline $\begin{array}{l}\text { The sense around here is that } \\
\text { employee learning is an } \\
\text { investment, not an expense. }\end{array}$ & $.9 \%$ & $.9 \%$ & $2.0 \%$ & $9.2 \%$ & $22.8 \%$ & $32.4 \%$ & $31.8 \%$ & 1,002 \\
\hline $\begin{array}{l}\text { Learning in our business is } \\
\text { seen as a key commodity } \\
\text { necessary to guarantee } \\
\text { business survival. }\end{array}$ & $1.1 \%$ & $1.8 \%$ & $1.7 \%$ & $11.2 \%$ & $23.9 \%$ & $29.6 \%$ & $30.7 \%$ & 1,002 \\
\hline SHARED VISION & & & & & & & & \\
\hline $\begin{array}{l}\text { There is a commonality of } \\
\text { purpose in our business. }\end{array}$ & $.8 \%$ & $.7 \%$ & $1.0 \%$ & $12.6 \%$ & $21.3 \%$ & $34.0 \%$ & $29.6 \%$ & 1,000 \\
\hline $\begin{array}{l}\text { There is total agreement on } \\
\text { our business's vision across } \\
\text { all levels, functions and } \\
\text { divisions. }\end{array}$ & $1.1 \%$ & $1.5 \%$ & $4.8 \%$ & $15.3 \%$ & $26.2 \%$ & $31.1 \%$ & $20.0 \%$ & 997 \\
\hline $\begin{array}{l}\text { All employees are committed } \\
\text { to the goals of this business. }\end{array}$ & $.8 \%$ & $.9 \%$ & $2.9 \%$ & $13.5 \%$ & $22.2 \%$ & $33.8 \%$ & $25.9 \%$ & 996 \\
\hline $\begin{array}{l}\text { Employees view themselves } \\
\text { as partners in charting the } \\
\text { direction of the business. }\end{array}$ & $1.0 \%$ & $2.3 \%$ & $7.1 \%$ & $20.3 \%$ & $23.7 \%$ & $27.3 \%$ & $18.3 \%$ & 989 \\
\hline $\begin{array}{l}\text { OPEN MINDEDNESS } \\
\text { We are not afraid to reflect } \\
\text { critically on the shared } \\
\text { assumptions we have made } \\
\text { about our customers. }\end{array}$ & $1.1 \%$ & $.9 \%$ & $1.9 \%$ & $20.3 \%$ & $23.4 \%$ & $31.3 \%$ & $21.1 \%$ & 995 \\
\hline $\begin{array}{l}\text { Employees in this business } \\
\text { realise that the very way they } \\
\text { perceive the marketplace } \\
\text { must be continually } \\
\text { questioned. }\end{array}$ & $1.6 \%$ & $2.0 \%$ & $4.7 \%$ & 28.1 & $26.4 \%$ & $22.5 \%$ & $14.7 \%$ & 989 \\
\hline $\begin{array}{l}\text { We rarely collectively } \\
\text { question our own business } \\
\text { about the way we interpret } \\
\text { customer information. }\end{array}$ & $15.4 \%$ & $19.1 \%$ & $20.9 \%$ & $21.5 \%$ & $12.9 \%$ & $6.9 \%$ & $3.4 \%$ & 996 \\
\hline LEARNING FROM CRISES & & & & & & & & \\
\hline
\end{tabular}




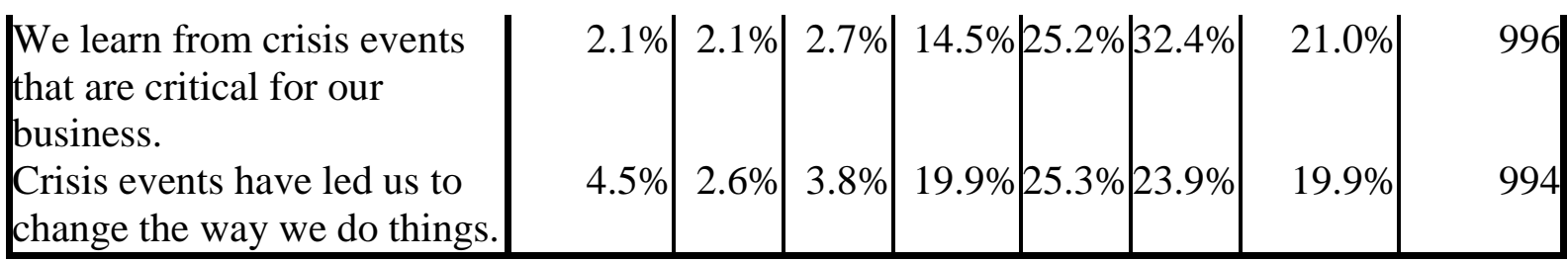

Total refers only to respondents answering the actual survey question

Statements in italics are worded in reverse outlook to others. 